\title{
FUNCTIONAL INTERACTION OF PELVIC FLOOR, DIAPHRAGM AND TRUNK MUSCLES AMONG MEN WITH PROSTATE CANCER
}

\author{
Brigita Zachovajevienè $^{1,3}$, Laimonas Šiupšinskas ${ }^{1}$, Pavelas Zachovajevas ${ }^{2,3}$, \\ Daimantas Milonas ${ }^{1}$, Loreta Lapinskaite ${ }^{1}$ \\ Lithuanian University of Health Sciences, Institute of Sport ${ }^{l}$, Kaunas, Lithuania \\ Lithuanian Academy of Physical Education', Kaunas, Lithuania \\ Kaunas College $e^{3}$ Kaunas, Lithuania
}

\begin{abstract}
Research background and hypothesis. The absolute dominance of the isolated muscle presentation as the first and last word in muscular anatomy leaves the current generation of therapists unlikely to think any other way (Myers, 2009). Hypothesis: functional relationships could be found between pelvic floor, diaphragm, and trunk muscles in men with prostate cancer.

Research aim. The aim of the study was to evaluate functional associations between pelvic floor, diaphragm, and trunk muscles among men with prostate cancer.

Research methods. The study included 81 male volunteers diagnosed with prostate cancer with measurements conducted one day before radical prostatectomy. Pelvic floor muscle strength and endurance were measured using "Peritron 9300" device, the strength of diaphragm - with "MicroRPM", the strength of transversus abdominis muscle - with "Stabilizer". Trunk muscles were tested using tests for static postural endurance of abdominal and back muscles. Associations were estimated using Pearson's correlation coefficient (r).

Research results. Analysis of functional indicators of muscles demonstrated high linear associations between strength of pelvic floor and diaphragm $(\mathrm{r}=0.79)$, between strength of diaphragm and exhalation muscles $(\mathrm{r}=0.78)$, and between static endurance of abdominal and back muscles $(r=0.72)$. We determined moderate correlations between endurance of pelvic floor and strength of transversus abdominis muscle $(r=0.59)$, between strength of transversus abdominis and static endurance of abdominal muscles $(\mathrm{r}=0.69)$, between strength of diaphragm and static endurance of abdominal $(\mathrm{r}=0.56)$ and back muscles $(\mathrm{r}=0.51)$, between the strength of exhalation muscles and static endurance of abdominal muscles $(r=0.57)$ and strength of pelvic floor $(r=0.65)$, between strength of pelvic floor and static endurance of back muscles $(\mathrm{r}=0.50)$. Low correlations were found between strength of pelvic floor and transversus abdominis $(\mathrm{r}=0.31)$ and static endurance of abdominal muscles $(\mathrm{r}=0.44)$, between endurance of pelvic floor and exhalation muscles $(r=0.37)$, and finally between transversus abdominis and static strength of back muscles $(\mathrm{r}=0.39)$. All correlations were statistically significant $(\mathrm{p}<0.01)$.

Discussion and conclusions. The findings showed positive associations among different functional indicators of muscles: strength of pelvic floor correlates with endurance of pelvic floor muscles, static abdominal and back muscles, strength of diaphragm, and transversus abdominis muscles. The results of this study confirm that functional associations between pelvic floor, diaphragm, and trunk muscles exist.
\end{abstract}

Keywords: abdominal muscles, static postural endurance, respiration, core stability.

\section{INTRODUCTION}

$\mathrm{T}$ The human locomotor system is, like nearly every other fascial structure in the body, constructed in doublebag fashion. Muscles are almost universally studied as isolated motor units. Such study ignores the longitudinal effects through this outer bag, as well as latitudinal 
(regional) effects now being exposed by research. Now it is clear that fascia distributes to strain laterally to neighboring myofascial structures; so that the pull on the tendon at one end is not necessarily entirely taken by the insertion at the other end of the muscle (Myers, 2009).

It is generally assumed that fascia is solely a passive contributor to biomechanical behavior, by transmitting tension which is created by muscles or other forces, but there are recent hints which indicate that fascia may be able to contract autonomously and thereby play a more active role (Schleip, 2006).

The central nervous system coordinates the motor activities of all trunk muscles (including the diaphragm) during both postural and respiratory tasks. Modulation of intraabdominal pressure occurs through coordinated activity of the diaphragm, abdominal and pelvic floor muscles (PFM), and such modulation may be important for the control of spinal stability (Hodges et al., 2000 a).

The data also indicate that PFM activity is modulated during quiet breathing. However, this activity is more closely associated with the activity of the abdominal muscles than with changes in intraabdominal pressure (IAP). During quiet breathing in standing, PFM activity was modulated with respiration (Smith et al., 2006). It was hypothesized that PFM activity would be linked to periods of increased IAP to meet the demands of continence and control of pelvic viscera. During quiet breathing, IAP increases during inspiration in conjunction with diaphragm activity. However, as IAP is modulated during the respiratory cycle, it is likely that PFM activity may be modulated during other respiratory tasks, including quiet breathing (Hodges et al., 2007). P. Neumann et al. (2002) found that PFM are also likely to be active with respiratory tasks. It is well accepted that PFM activity accompanies coughing and resisted expiration.

Coactivation of the diaphragm and abdominal muscles causes a sustained increase in intraabdominal pressure, whereas inspiration and expiration are controlled by opposing activity of the diaphragm and abdominal muscles to vary the shape of the pressurized abdominal cavity (Hodges et al., 2000 a). Activation of the levator muscle during abdominal pressurization is important to this stabilization process. The integrity of the connection between the vaginal wall and tendinous arch also plays an important role. (Delancey et al.,
2004). Functionally, the levator ani muscle and the endopelvic fascia interact to maintain continence and pelvic organ support (Ashton-Miller et al., 2007). S. J. Madill and L McLean (2006) stated that during voluntary PFM contractions, an increase in lower intravaginal pressure is not solely the product of PFM activation, but involves a specific coordination between the PFM, transversus abdominis (TrA), rectus abdominal, and internal oblique muscles (Madill, McLean, 2006). The TrA generated $224 \%$ more activity during the pelvic floor contractions than during the abdominal hollowing exercises that were aimed at isolating and maximally activating this muscle (Urquhart et al., 2005).

B. Junginger et al. (2010) revealed that bladder neck elevation occurred only during PFM and TrA contractions. They also reported that abdominal muscles in continent women contribute significantly to the development of lower intravaginal pressure during voluntary PFM contractions, particularly in the latter part of the contraction.

R. R. Sapsford et al. (2001 a) reported that the PFMs were activated in each of three exercises: abdominal hollowing, abdominal bracing, and abdominal bracing with breath hold and also that the abdominal muscles were recruited when a PFM contraction was performed. R. R. Sapsford et al. (2001 b) and P. W. Hodges et al. (2000 a) reported that with a maximal abdominal muscle contraction, the PFMs were activated to the same level as with a maximal voluntary PFM contraction. Similarly, P. Neumann and V. Gill (2002) found that it was not possible for continent women to fully contract their PFMs without contracting the TrA and the IO muscles as well.

PFM are likely to contribute to control of the spine and pelvis. Furthermore, PFM activity may also indirectly contribute to lumbopelvic control through an effect on tension developed in the thoracolumbar fascia; hoop tension of the fascia from contraction of the abdominal muscles is dependent on IAP. It is thought that synergistic activation from the abdominal muscles enhances a woman's ability to contract the PFMs (Madill, McLean, 2008).

K. Bø (2004) found that three physiotherapists who were well trained in isolating PFM contractions were not able to perform a maximal PFM contraction without a rise in EMG activity in the lower portion of rectus abdominal (RA) muscle. PFMs and the abdominal muscles contract synergistically in continent women and it may be 
counterproductive to teach to contract the PFMs in isolation when performing PFM exercises.

L. Penning (2000) determined that functionally, the transversus abdominis, psoas, quadratus lumborum and lumbar multifidus have each been described as contributing to the control of lumbar segmental motion via either the maintenance of spinal equilibrium or the development of intersegmental stiffness.

In his book T. W. Myers (2009) presented the anatomical connections of all body muscles, also including diaphragm, pelvic floor and trunk muscles. Fascia is the structural connector of muscles, building the strong, pliable stuff which holds us together, forming the shared and communicative environment for all our cells.

Functional relations of abdomen and back muscles were described by numerous studies done by P. W. Hodges and others. The functional connections of pelvic floor and diaphragm are discussed in the scientific literature by M. D. Smith et al. (2006), P. Neumann et al. (2002). A number of studies were carried at analyzing the importance of pelvic floor muscles in women health and pathologies. Despite the anatomical differences there is a lack of evidence about the functional characteristics of pelvic floor in men.

The aim of this study was to evaluate functional associations between pelvic floor, diaphragm, and trunk muscles among men with prostate cancer. We hypothesized that between pelvic floor, diaphragm, and trunk muscles in men with prostate cancer there must be functional relationships.

\section{RESEARCH METHODS}

The study included 81 male volunteers diagnosed with prostate cancer. The study was conducted at Department of Urology, Hospital of Lithuanian University of Health Sciences Kauno Klinikos during 2010-2012. The study obtained ethical approval No. BE-2-61 by Kaunas Regional Committee for Biomedical Research.

Objectively pelvic floor muscles strength and endurance were measured using "Peritron 9300" device, the strength of diaphragm was estimated using "MicroRPM", the strength of transversus abdominal was assessed using "Stabilizer". The trunk muscles were tested using tests for static endurance of abdominal and back muscles. All measurements were conducted one day before radical prostatectomy surgery.
The assessment of pelvic floor muscle strength and endurance was done with a patient in left lateral position and knees drawn up at about $45^{\circ}$. For higher accuracy and repeatability participant had to be in the same position each session and the anal sensor had to be inserted at the same amount. For evaluation of pelvic floor strength, a person was asked to squeeze his muscles at maximum. The maximum result (in $\mathrm{cm}_{2} \mathrm{O}$ ) was calculated as follows: within 1.8 second there were three readings recorded - every 0.6 seconds each. For the evaluation of pelvic floor endurance, a person was asked to squeeze and keep his muscles in maximal contraction as long as possible. The result of endurance was set as a time (in seconds) between maximal contraction and decrease of maximal contraction by more than $5 \%$. The measurements of strength and endurance in two sessions and their arithmetic mean were used for analyses.

Strength of breathing muscles (in $\mathrm{cm} \mathrm{H}_{2} \mathrm{O}$ ) was evaluated as maximum inhalation pressure (PImax) and maximum exhalation pressure (PEmax). The procedure was conducted in sitting position: a patient was asked to breathe in to maximum and exhale to maximum, and then vice versa. Result was recorded only when the person had maximum inhalation or exhalation shorter than 3 seconds. For accurate measurements the tube was essential.

The assessment of the strength of transversus abdominis muscle was performed in position lying on abdomen and making contracting movement of abdominal wall. The person was asked to lie on belly with neck and head relaxed and kept at middle line of the body. Device pillow was set at lower abdomen so that the distal margin of the pillow would converge with anterior iliac line. The stabilizer pressure was set at $70 \mathrm{mmHg}$. The person was asked to contract his lower abdomen slowly without supporting movements of spinal cord, hips, shoulders or pelvis, and keep such position for 10 seconds with regular breathing.

Decreasing pressure on stabilizer manifests in negative numbers which shows improving TrA activity. The study results were considered as positive if the pressure on device decreased to $1 \mathrm{mmHg}$ (in ideal case to $-10 \mathrm{mmHg}$ ). If, however, the pressure increased, this was observed in positive numbers on the device and showed improper contraction of TrA and was defined as 0 . The measurement was performed in two sessions and their arithmetic mean was used for analyses.

The static endurance of abdominal muscles was tested lying supine with bend knees and hips 
$45^{\circ}$. The person was asked to raise his head and shoulders with arms kept across the body and keep this position as long as possible. The static endurance of back muscles was tested lying prone. The person was asked to raise his head and shoulders with arms kept across the body and keep this position as long as possible. The static endurance of abdominal and back muscles at norm is 300 seconds ( 5 minutes). The measurement was performed in one session (due to fatigue) and the mean was used for analyses.

Statistical data analysis was performed using SPSS for Windows 20.0 and Microsoft Office Excel 2010 software. Functional associations were evaluated according to Pearson correlation coefficient $r$, where $r=0$ is considered as no correlation, $0.0<|\mathrm{r}| \leq 0.3$ as very low correlation, 0.3 $<|\mathrm{r}| \leq 0.5$ - low correlation, $0.5<|\mathrm{r}| \leq 0.7$-moderate correlation, $0.7<|\mathrm{r}| \leq 0.9$ - high correlation, and $0.9<|\mathrm{r}| \leq 1.0$ - very high correlation. Statistical significance level was set at $95 \%(\mathrm{p}<0.05)$.

\section{RESEARCH RESULTS}

The analysis of functional associations between the strength of pelvic floor muscles (PFM) and other muscles showed that it strongly and significantly $(\mathrm{p}<0.001)$ correlated with the strength of diaphragm $(\mathrm{r}=0.79)$. The association between PFM and diaphragm was linear and it is presented in Figure 1.

The association of strength between PFM and exhalation muscles was found to be at the level of moderate linear correlation $(\mathrm{r}=0.65)$ and this was statistically significant $(p<0.001)$. Similarly, but lower moderate correlation $(r=0.50)$ was found between the strength of PFM and endurance of back muscles $(p<0.001)$. Even lower though statistically significant correlations were found between strength of PFM and endurance of abdominal muscles $(r=0.44 ; p<0.001)$, strength of transversus abdominis muscle $(\mathrm{r}=0.32 ; \mathrm{p}=0.004)$ and endurance of PFM $(r=0.29 ; p=0.009)$. Thus,
Figure 1. Correlation between strength of pelvic floor muscles and of diaphragm for the study subjects

Note. $r=0.79, \mathrm{p}<0.001$.

Figure 2. Correlations between the strength of diaphragm and of exhalation muscles for the study subjects
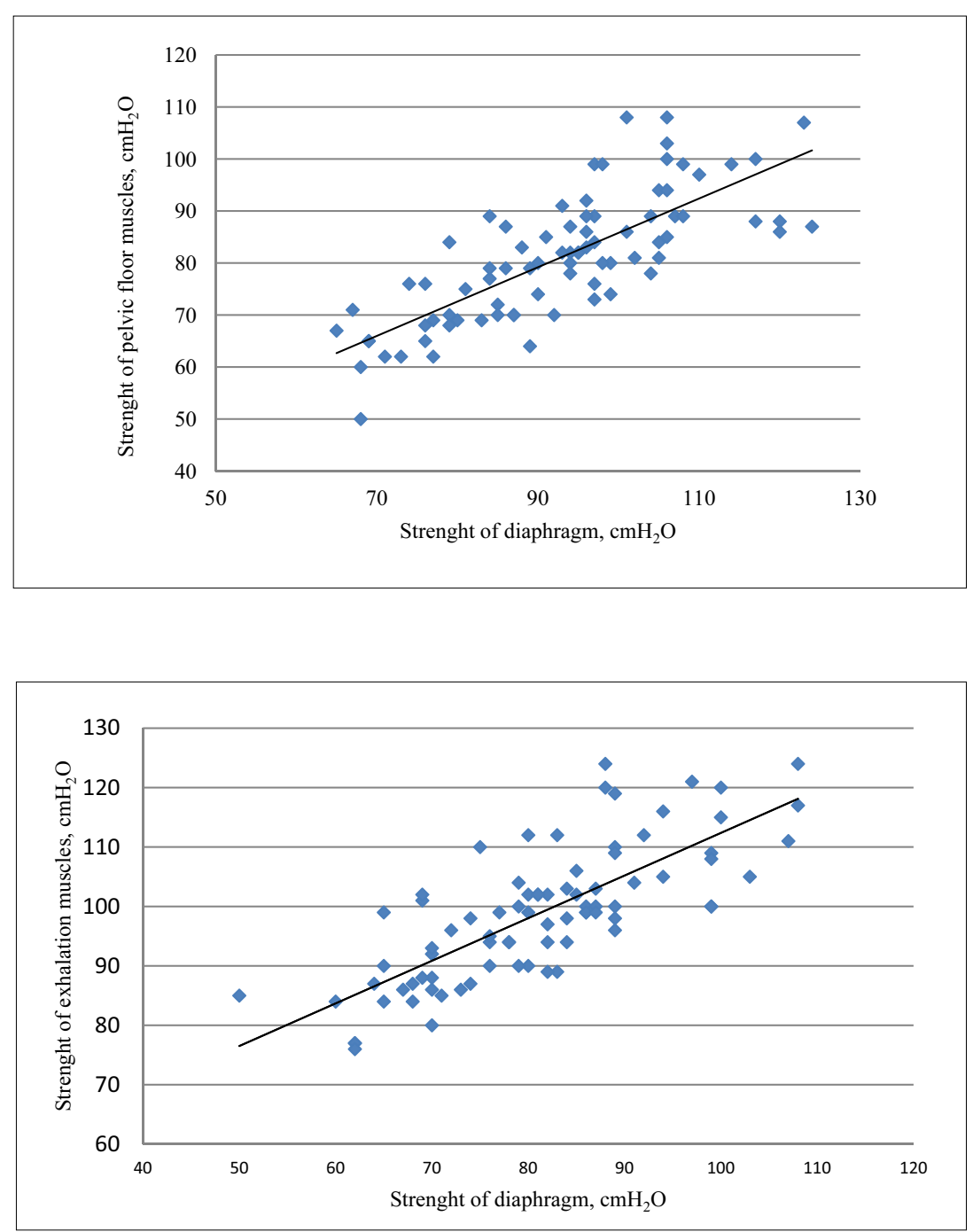

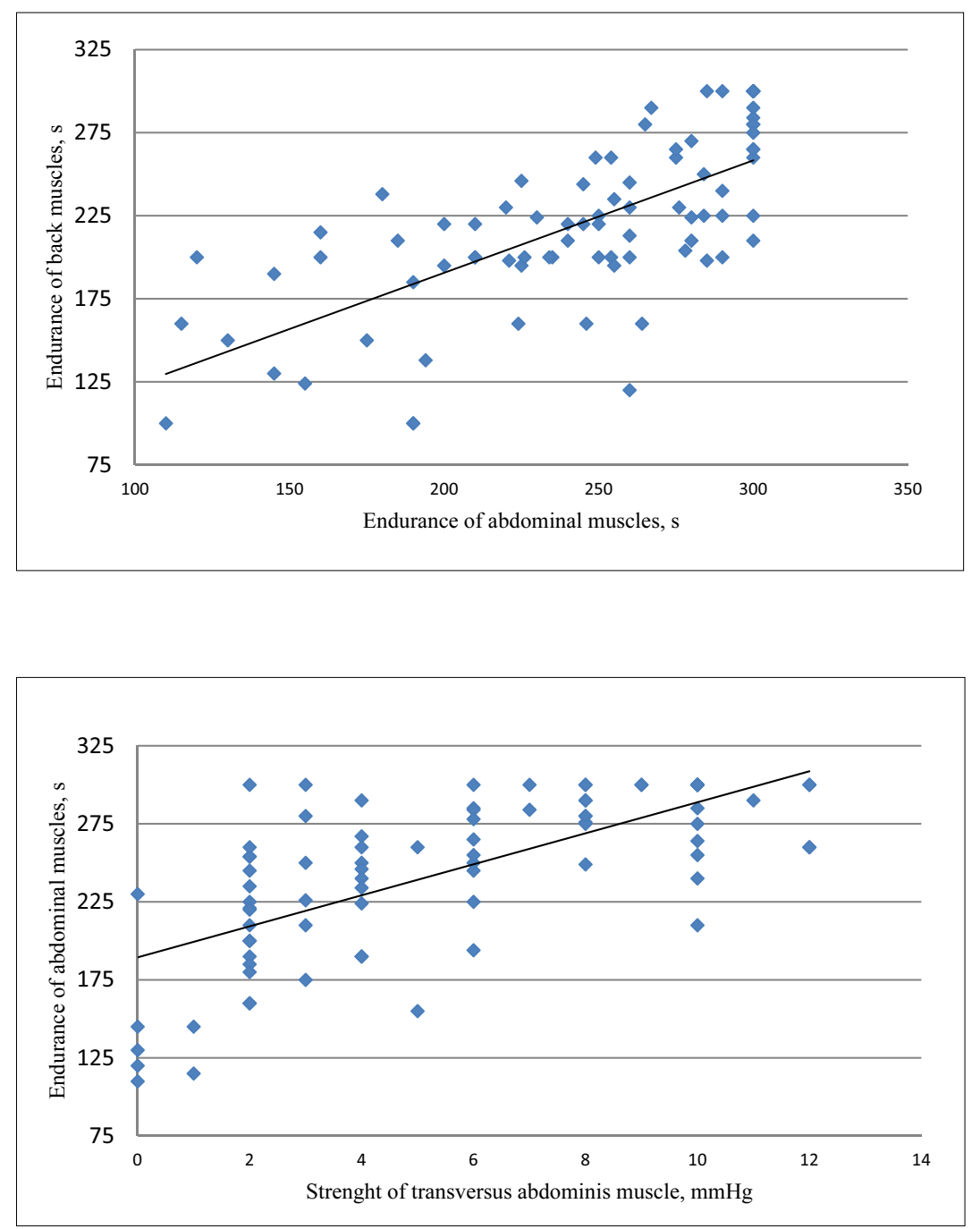

Figure 3. Correlations between the endurance of back and abdominal muscles for the study subjects

Note. $r=0.72 ; p<0.001$

Figure 4. Correlations between the strength of transversus abdominis muscle and endurance of abdominal muscles for the study subjects

Note. $r=0.69 ; \mathrm{p}<0.001$. it can be concluded that with the increase of PFM strength, the strength of diaphragm, exhalation muscles, and transversus abdominis muscle increases too as well as endurance of abdominal, back, and pelvic floor muscles.

The evaluation of functional associations of strength of diaphragm showed that there was a strong positive linear correlation with the strength of exhalation muscles $(r=0.78)(p<0.001)$, which is shown in Figure 2.

The strength of diaphragm muscle statistically significantly and positively correlated with endurance of abdominal $(\mathrm{r}=0.56)$ and back $(\mathrm{r}=0.51)$ muscles $(\mathrm{p}<0.001)$.

Analysis of associations of endurance of abdominal muscles (Figure 3) revealed strong positive correlation with endurance of back muscles $(\mathrm{r}=0.72)$ and this was statistically significant $(\mathrm{p}<0.001)$.

Endurance of pelvic floor muscles showed functional association at moderate correlation level with transversus abdominis muscle $(\mathrm{r}=0.59$; $\mathrm{p}<0.001)$. Meanwhile the correlation with the strength of exhalation muscles was low $(r=0.37)$, though statistically significant $(\mathrm{p}=0.001)$. Similarly, low positive correlations were found between the endurance of PFM and the endurance of abdominal $(\mathrm{r}=0.36)$ and back $(\mathrm{r}=0.34)$ muscles, and still statistically significant $(\mathrm{p}=0.001$ and $p=0.002$, respectively). In general, it can be stated that with the increase of endurance of pelvic floor muscles, the strength of exhalation muscles as well as endurance of abdominal and back muscles increases too.

Analysis of strength of transversus abdominis muscle revealed moderate $(r=0.69)$ statistically significant correlation with the endurance of abdominal muscles $(\mathrm{p}<0.001)$, which is presented in Figure 4.

The correlation between endurance of back muscles and strength of transversus abdominis muscle was low $(r=0.39)$, positive and statistically 
significant $(\mathrm{p}<0.001)$. Similarly, low positive correlations were found with the strength of diaphragm $(r=0.40)$ and exhalation muscles $(\mathrm{r}=0.42)(\mathrm{p}<0.001)$.

In our study, strength of exhalation muscles moderately correlated with the endurance of abdominal muscles $(r=0.57)$ and slightly weaker with endurance of back muscles $(\mathrm{r}=0.48)$ $(\mathrm{p}<0.001)$.

\section{DISCUSSION}

Our study results demonstrated that the strength of pelvic floor muscles correlated with that of diaphragm. This means that the activation of diaphragm has influence on the activity of pelvic floor muscles and vice versa. This finding supports M. D. Smith et al.'s (2006) results showing that during quiet breathing in a standing position, PFM activity was modulated with respiration. Based on their own studies, P. W. Hodges et al. (2007) state that IAP is modulated during the respiratory cycle, while PFM activity is modulated during other respiratory tasks, including quiet breathing. Thus it can be stated that during the breathing, pelvic floor muscles undergo activation as a reaction to IAP. Our study shows that both the strength of transversus abdominis muscle and the endurance of static abdominal muscles correlate with the strength of diaphragm and exhalation muscles which supports the findings of abovementioned researchers. It can be concluded that during activation of breathing muscles the strength of pelvic floor muscles is also improving.

Additionally, our study estimated the associations between strength and endurance of pelvic floor and abdominal muscles. Our results also support the previous findings by P. Neumann and V. Gill (2002), and R. R. Sapsford et al. (2001) who suggested that synergistic activity of abdominal and pelvic floor muscles was important in terms of generating adequate urethral closing pressures. $\mathrm{K}$. Bø et al. (1990) also found the high crosscorrelation coefficients between the PFMs and the abdominal muscles that were computed from the 30 seconds series of repeated contraction data, which was likely the result of muscle synergistic action. This is a logical synergy as the PFMs close the pelvic outlet and these muscles and their associated fascia are the only structures within the pelvis capable of resisting gravitational forces and intraabdominal pressure.
S. J. Madill et al. (2006) reported that the high relative activation levels for TrA and internal oblique muscle are more closely tied synergistically to the PFMs than rectus abdominis and external oblique muscle. This finding is consistent with our study which found that TrA moderately correlated with the endurance of pelvic floor muscles. Coactivation of the abdominal muscles with the PFMs has also been previously reported by R. R. Sapsford et al. (2001). The results of this study showed that thickness of the TrA and internal oblique muscle changes during contraction of PFM. This indicates that there exists a coactivation between pelvic floor and abdominal muscles during PFM contraction. This finding is in accordance with EMG studies showing a co-contraction of abdominal muscles during PFM contraction reported by A. M. Arab and M. Chehrehrazi (2011). They also found that maximal contraction of the PFM was associated with the activity of all abdominal muscles which increases the IAP as well as TrA muscle.Our study findings also demonstrate that the activation of transversus abdominis muscle leads to activation of pelvic floor muscles. Similarly, endurance of abdominal muscles has also influence on endurance of pelvic floor muscles.

We found that the correlation between endurance of transversus abdominis muscle and that of abdominal muscles was moderately positive, which can be explained by synergy of those muscles. During the test of endurance of abdominal muscles, the activation of transversus abdominis muscle takes place too, therefore its condition has certain impact on the test results - the higher activity of transversus abdominis muscle, the higher endurance of abdominal muscles. These findings support the results of study by S. J. Madill and L. McLean. (2006).

A number of studies done by P. W. Hodges et al. (2003) and L. Penning (2000) have reported on the anatomical, biomechanical or neurophysiologic characteristics and relations of the transversus abdominis, psoas, quadratus lumborum and lumbar multifidus muscles in the context of spinal stability. In our study we found functional relationships between endurance of abdominal and back muscles. This can be explained by antagonistic nature of those muscle groups and in case of balance between those muscles they have influence on each other. 


\section{CONCLUSIONS AND PERSPECTIVES}

1. The findings showed that functional indicators of muscles were directly associated with each other in men with prostate cancer.

2. The strength of pelvic floor correlated with endurance of pelvic floor muscles, endurance of abdominal and back muscles, strength of diaphragm and transversus abdominis muscles in men with prostate cancer.

3. The results of this study confirmed that functional relations between pelvic floor, diaphragm, and trunk muscles existed in men with prostate cancer.

We think that our findings have important clinical implications for PFM rehabilitation. First, the results of the study suggest that the contraction of PFM is associated with strength of diaphragm, status of abdominal muscles and activity of transversus abdominis muscle. Exercises of these muscles should be considered in the rehabilitation. Attempts to normalise the coordination between abdominal and PFM may be an important step in rehabilitation. This requires multifaceted assessment of the activity of PFM and abdominal muscles.

The second clinical implication is that the initial activation of PFM could be achieved by gentle contraction of transversus abdominis muscle in some men. This might be helpful in men who have problems with the perception of their pelvic floor and who are not able to contract their PFM because of decreased pelvic floor awareness.

In the future it would be interesting to analyse how such functional relationships change following surgery, when poor balance of muscles appears and how the muscles change throughout the rehabilitation process.

\section{REFERENCES}

Arab, A. M., Chehrehrazi, M. (2011). The response of the abdominal muscles to pelvic floor muscle contraction in women with and without stress urinary incontinence using ultrasound imaging. Neurourology and Urodynamics Journal, 30 (1), 117-120.

Ashton-Miller, J. A., DeLancey, J. O. (2007). Functional anatomy of the female pelvic floor. Annals of the New York Academy of Sciences, 1101, 266-296.

Bø, K., Kvarstein, B., Hagen, R., Larsen, S. (1990). Pelvic floor muscle exercise for the treatment of female stress urinary incontinence: II. Validity of vaginal pressure measurements of pelvic floor muscle strength and the necessity of supplementary methods for control of correct contraction. Neurourology and Urodynamics Journal, 9, 479-487.

$\mathrm{B} ø, \mathrm{~K}$. (2004). Pelvic floor muscle training is effective in treatment of female stress urinary incontinence, but how does it work? International Urogynecology Journal, 15 (2), 76-84.

Delancey, J. O., Ashton-Miller, J. A. (2004). Pathophysiology of adult urinary incontinence. Gastroenterology, 126, 23-32.

Hodges, P. W., Gandevia, S. C. (2000 a). Activation of the human diaphragm during a repetitive postural task. The Journal of Physiology, 522, Pt 1, 165-175.

Hodges, P. W., Gandevia, S. C. (2000 b). Changes in intra-abdominal pressure during postural and respiratory activation of the human diaphragm. Journal of Applied Physiology, 89, 967-976, pmid:10956340.

Hodges P. W., Kaigle-Holm, A., Holm, S. et al. (2003). Intervertebral stiffness of the spine is increased by evoked contraction of transversus abdominis and the diaphragm In vivo porcine studies. Spine, 28 (23), 2594-2601.
Hodges, P. W., Sapsford, R., Pengel, L. H. (2007). Postural and respiratory functions of the pelvic floor muscles. Neurourology and Urodynamics Journal, 26 (3), 362-371.

Howard, D., Miller, J. M., DeLancey, J. O. L. et al. (2000). Differential effects of cough, valsalva, and continence status on vesical neck movement. American Journal of Obstetrics and Gynecology, 95, 535-540.

Jemmett, R. S., MacDonald, D. A., Agur, A. M. R. (2004). Anatomical relationships between selected segmental muscles of the lumbar spine in the context of multiplanar segmental motion: A preliminary investigation. Manual Therapy, 9 (4), 203-210.

Junginger, B., Baessler, K., Sapsford, R., Hodges, P. W. (2010). Effect of abdominal and pelvic floor tasks on muscle activity, abdominal pressure and bladder neck. International Urogynecology Journal, 21 (1), 69-77.

Madill, S. J., McLean, L. (2008). Quantification of abdominal and pelvic floor muscle synergies in response to voluntary pelvic floor muscle contractions. Journal of Electromyography \& Kinesiology, 18 (6), 955-964.

Madill, S. J., McLean, L. (2006). Relationship between abdominal and pelvic floor muscle activation and intravaginal pressure during pelvic floor muscle contractions in healthy continent women. Neurourology and Urodynamics Journal, 25 (7), 722-730.

Myers, T. W. (2009). Anatomy Trains Miofascial Meridians for Manual and Movement Therapist. Churchill Livingstone Elsevier.

Neumann, P., Gill, V. (2002). Pelvic floor and abdominal muscle interaction: EMG activity and intra-abdominal pressure. International Urogynecology Journal and Pelvic Floor Dysfunction, 13, 125-132. 
Penning, L. (2000). Psoas muscle and lumbar spine stability: A concept uniting existing controversies. Critical review and hypothesis. European Spine Journal, 9 (6), 577-585.

Sapsford, R. R., Hodges, P. W. (2001a). Contraction of the pelvic floor muscles during abdominal manoeuvres. Archives of Physical Medicine and Rehabilitation, 82, 1081-1088.

Sapsford, R. R., Hodges, P. W., Richardson, C. A. et al. (2001 b). Co-activation of the abdominal and pelvic floor muscles during voluntary exercises. Neurourology and Urodynamics Journal, 20, 31-42.
Schleip, R. (2006). Active fascial contractility. Proceedings of the 1st International Congress of Osteopathic Medicine, Freiburg, Germany (pp. 35-36). Munich: Elsevier.

Smith, M. D., Russell, A., Hodges, P. W. (2006). Disorders of breathing and continence have a stronger association with back pain than obesity and physical activity. American Journal of Physiology, 52,11-16.

Urquhart, D. M., Hodges, P. W., Allen, T. J. et al. (2005). Abdominal muscle recruitment during a range of voluntary exercises. Manual Therapy, 10,144-153.

\title{
PROSTATOS VĖŽIU SERGANČIŲ VYRŲ DUBENS DUGNO, DIAFRAGMOS IR LIEMENS RAUMENŲ FUNKCINĖS SĄSAJOS
}

\author{
Brigita Zachovajevienè ${ }^{1,3}$, Laimonas Šiupšinskas ${ }^{1}$, Pavelas Zachovajevas ${ }^{2,3}$, \\ Daimantas Milonas ${ }^{1}$, Loreta Lapinskaité ${ }^{1}$ \\ Lietuvos sveikatos mokslu universitetas, Sporto institutas ${ }^{1}$, Kaunas, Lietuva \\ Lietuvos kūno kultūros akademija², Kaunas, Lietuva \\ Kauno kolegija ${ }^{3}$, Kaunas, Lietuva
}

\section{SANTRAUKA}

Tyrimo pagrindimas ir hipotezė. Žmogaus raumenys nėra izoliuoti vieni nuo kitų. Jungtys, egzistuojančios tarp raumenų, specialistus, dirbančius su žmogaus kūnu, skatina mąstyti kitaip (Myers, 2009). Hipotezė: tarp vyru, sergančių prostatos vėžiu, dubens dugno, diafragmos ir liemens raumenų egzistuoja funkciniai ryšiai.

Tikslas - įvertinti dubens dugno, diafragmos ir liemens raumenų funkcines sąsajas tarp vyrų, sergančių prostatos vèžiu.

Metodai: Buvo tiriamas 81 savanoris vyras. Jiems buvo diagnozuotas prostatos vėžys. Matavimai atlikti dieną prieš prostatos šalinimo operaciją. Dubens dugno raumenu jèga ir ištvermè buvo matuojama naudojant perineometrą „Peritron 9300“, diafragmos jèga - "MicroRPM“", skersinio pilvo raumens aktyvumas - „Stabilizer“, o liemens raumenų statinè ištvermé i̇vertinta atliekant pilvo ir nugaros statinius atlikties testus. Funkcinès sąsajos (rodiklių priklausomybè) įvertintos skaičiuojant Pirsono koreliacijos koeficientą (r).

Rezultatai. Tarp dubens dugno ir diafragmos raumenu jègos $(\mathrm{r}=0,79)$, diafragmos ir iškvėpimo raumenu jègos $(\mathrm{r}=0,78)$ bei tarp pilvo ir nugaros raumenu statinès ištvermès $(\mathrm{r}=0,72)$ nustatyta stipri tiesinè priklausomybè. Vidutinio stiprumo tiesinè priklausomybè nustatyta tarp šių raumenų: dubens dugno raumenų ištvermès ir skersinio pilvo raumens jègos $(r=0,59)$, skersinio pilvo raumens jẻgos ir statinès pilvo raumenų ištvermès $(r=0,69)$, diafragmos jègos ir statinès pilvo $(r=0,56)$, nugaros raumenu $(r=0,51)$ ištvermès bei iškvèpimo raumenu jègos ir statinès pilvo raumenų ištvermès $(r=0,57)$ bei dubens dugno jègos $(r=0,65)$, tarp dubens dugno raumenu jègos ir statinès nugaros ištvermès $(r=0,50)$. Silpna tiesinè priklausomybè nustatyta tarp dubens dugno raumenų ir skersinio pilvo raumens jègos $(\mathrm{r}=0,32)$ bei statinès pilvo ištvermès $(\mathrm{r}=0,44)$, dubens dugno ištvermès ir iškvèpimo raumenų jègos $(r=0,37)$ bei skersinio pilvo ir statinès nugaros raumenų ištvermès $(r=0,39)$. Visų funkcinių rodiklių koreliacijos statistiškai reikšmingos $(\mathrm{p}<0,01)$.

Aptarimas ir išvados. Tyrimas parode, kad raumenu funkciniai rodikliai tarpusavyje susiję: dubens dugno raumenu jëga koreliuoja su dubens dugno raumenų ištverme, statine pilvo ir nugaros raumenų ištverme, diafragmos ir skersinio pilvo raumens ištverme. Galima teigti, kad tarp dubens dugno, pilvo bei liemens raumenų egzistuoja funkcinès sąsajos.

Raktažodžiai: pilvo raumenys, statinė ištvermè, kvėpavimas, stabilumas.

Corresponding author Brigita Zachovajevienè

Lithuanian University of Health Sciences, Institute of Sport

Jankaus str. 2, LT-50275 Kaunas

Lithuania

Tel +37069875901

E-mail brigitaz@medi.lt 